\title{
Characterisitics Examination of Bentonite Mortar with Replacement of Cement
}

\author{
K. Anitha, T.P. Meikandaan, M. HemaPriya
}

\begin{abstract}
The experimental investigation on alternate concrete from aged volcanic ash or hydrated aluminium silicate was done by partially replacing bentonite with OPC. Bentonites consist of the fundamental elements of cement like silica, magnesium and calcium. The total assets of bentonite in the country are about 531 million tons bulk of the resource in Tamil Nadu.The partial replacement of bentonite with cement leads to reduction of cement content in concrete mix and furthermore decreases the transfer and contamination issues. Cylinders and cubes were casted and tested for the 7th, 14th and 28th days respectively.10, 20, 30, 40 and $50 \%$ replacement of bentonite with cement are done. Slump test are also done to study the workability characteristics of replacement concrete according to Indian standards. Finally the estimation was computed for all the partial replacement of concrete samples of bentonite according to percentage of mix.
\end{abstract}

Keywords - Volcanic ash, Slump test, Aluminium Silicate.

\section{INTRODUCTION}

Concrete is the most broadly utilized man-made construction material available on the world. Its popularity as a construction material is due to its economy, durability, insulation property, thermal property, ability to be mould in to desired shapes and its beauty[1]-[4]. Concrete is defined as the combination of the coarse aggregate, fine aggregate and binding material such as cement or lime with convenient prescribed quantity of water. Here cement is the important component because, cement is binding materialThe carbon-di-oxide emanations go about as a quiet executioner in nature as different structures. In this background, the quest for less expensive substitute to OPC is a needful one. Bentonite is basically high plastic dirt containing at the very least $85 \%$ earth mineral. There are two kinds of bentonite in particular, growing sort or sodium bentonite and non-expanding type or calcium bentonite. The business significance of bentonite depends more on its physic-compound properties instead of its substance structure[5]-[8]. Magnificent versatility and lubricity, high dry-holding quality, high shear and compressive quality, low penetrability and low compressibility make bentonite significant.

\section{A. Propoerties of Bentonite}

Bentonite is basically profoundly plastic clay containing at the very least $85 \%$ earth mineral, montmorillonite. There are

Revised Manuscript Received on October 22, 2019.

K. Anitha, Department of Civil Engineering, Bharath Institute of Higher Education and Research, Chennai , India. Email: anithakrish26@yahoo.co.in

T.P. Meikandaan, Department of Civil Engineering, Bharath Institute of Higher Education and Research, Chennai , India. Email: ganga_meik@yahoo.co.in

M. HemaPriya, Department of Civil Engineering, Bharath Institute of Higher Education and Research, Chennai , India. Email: meihemapriya@gmail.com two kinds of bentonites. To be specific, growing sort (or) sodium bentonite and non-expanding type (or) calcium bentonite.Some of the basic properties of this bentonite are tabulated below

\begin{tabular}{|l|c|}
\hline Type & Non-Swelling Bentonite (Calcium) \\
\hline Specific gravity & 3.60 \\
\hline Bulk density $(\mathrm{g} / \mathrm{cc})$ & 0.60 \\
\hline
\end{tabular}

Table - 1 Properties of Bentonite

\begin{tabular}{|c|c|c|}
\hline S. no & Chemical name & Results(\%) \\
\hline 1. & Manganese (Mn) & 0.022 \\
\hline 2. & Calcium (Ca) & 0.197 \\
\hline 3. & Potassium (k) & 0.486 \\
\hline 4. & Phosphorus (P) & 0.136 \\
\hline 5. & Titanium (Ti) & 1.803 \\
\hline 6. & Iron (Fe) & 4.759 \\
\hline 7. & Silica (Si) & 16.210 \\
\hline 8. & Aluminum (A1) & 5.752 \\
\hline
\end{tabular}

Table - 2 Chemical compositions of Bentonite

\section{EXPERIMENTAL RESULTS}

\section{A. Object of Testing}

For normal concrete, fine aggregates and cement were weighed and blended altogether; the ,coarse aggregate was then added and blended in with the above mentioned samples. The necessary measure of water was added and blended completely to get a uniform solid mass, and finally concrete is compacted by hand compaction according to Indian Standards techniques[9]-[11]. For setting up the cylinder and cube concrete samples, steel moulds of standard size were utilized. The fresh concrete was then poured into the respective moulds with utmost care and proper compaction should be done. After 24 hours all moulds should be de moulded and kept for curing. Then according to IS 456:2000 code all samples were tested on 7 th, 14 th and 28 th day. The following samples were casted with bentonite replaced concrete sample

1. 18 No's of cube sample size $150 \mathrm{~mm} \times 150 \mathrm{~mm} \times 150 \mathrm{~mm}$ were casted utilizing M20 grade concrete. Concrete samples with ordinary Portland cement

2. were utilized for the study of compressive strength of bentonite replaced concrete sample. 
3. 6 Nos. of cylinder concrete sample of size $150 \mathrm{~mm} \mathrm{x}$ $300 \mathrm{~mm}$ were casted for the study of split tensile strength test of bentonite replaced concrete sample

4. OPC was replaced with bentonite powder at $10 \%, 20 \%$, $30 \%, 40 \%$ and $50 \%$.

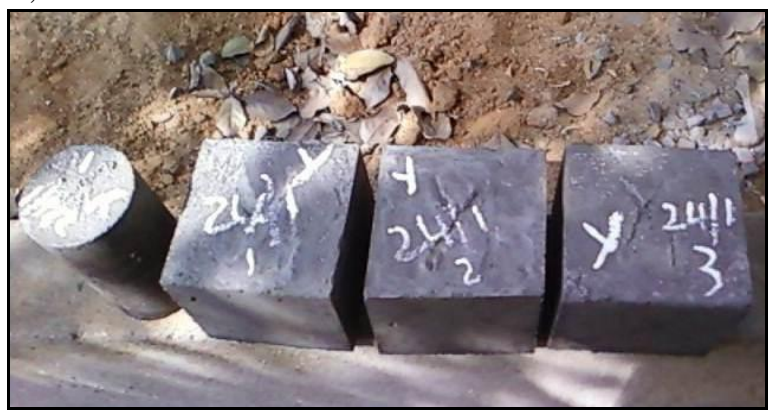

Figure - 1 Sample Specimens

\section{RESULT AND DISCUSSION}

Various properties of concrete incorporating bentonite at various replacement levels with fine aggregate levels were studied; results were compared and checked for compressive strength, of bentonite mix with ordinary mix. Test results were compared and shown in below table 3[12]-[13]

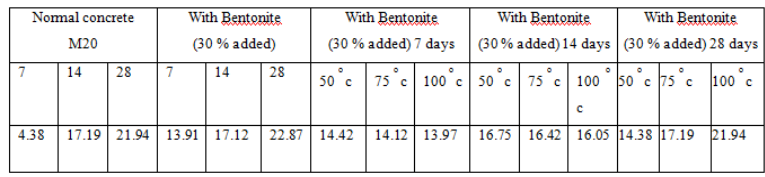

Table 3 - Comparison of compression strength for M20

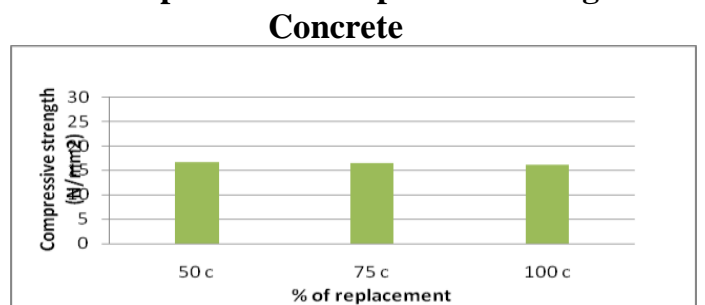

Figure - 2 Compressive Strength Results

\section{CONCLUSION}

Based on the limited experimental investigation on the compressive and split tensile strength of concrete, the following observations are made regarding the resistance of partially replaced bentonite powder. From the experimental study, replacement of cement with bentonite powder at $30 \%$ gives maximum strength and it is most economical one compared to normal concrete. Utilization of cement is reduced while using bentonite powder. Environmental effects due to the cement manufacturing are reduced through this project[30]-[34]. The mixture of Cement and bentonite is extremely versatile material and make an immense contribution to construction processes such as cut-off walls, permeation grouting, jet grouting, borehole sealing etc. The compression strength increases for added $30 \%$ bentonite, compare to nominal concrete $7,14, \& 28$ days. The compression strength decreases for added $30 \%$ Bentonite concrete cube at $500 \mathrm{C}, 750 \mathrm{C}, \& 1000 \mathrm{C}$.

\section{REFERENCES}

1. Sathish Kumar, K., Vinothkumar, S., Venkatakrishnaiah, R. \& Mohan, S.J. 2019, "Experimental investigation on rehabilitation of corroded concrete beam specimens", International Journal of Civil Engineering and Technology, vol. 10, no. 1, pp. 2949-2955.

2. Kanchanabhan, T.E., Krishnaiah, R.V., Dayakar, P. and Mani, A., 2019. A detailed study on green building concept in construction industry. International Journal of Civil Engineering and Technology, 10(1), pp. 2944-2948.

3. Mugilvani, P., Murugan, S.T., Kaviya, B. and Sathishkumar, K., 2019. Experimental investigation on nano concrete. International Journal of Civil Engineering and Technology, 10(1), pp. 907-912.

4. Vinothkumar, S., Sathishkumar, K., Anish, C. and Rajesh, S., 2019. Characteristic strength of concrete by partial replacement with sawdust and waste ceramic tiles. International Journal of Civil Engineering and Technology, 10(1), pp. 2821-2829.

5. Chitra, R., Thendral, S., Arunya, A. and Mohan, S.J., 2019. Experimental study on strength of concrete by partial replacement of fine aggregate with saw dust. International Journal of Civil Engineering and Technology, 10(1), pp. 2766-2769.

6. Mani, A., Meikandaan, T.P., Gowrishankar, P.G. and Kanchanabhan, T.E., 2019. A study on treatment of industrial effluent (dyeing) using moringa oleifera, tamarina indica as coagulants. International Journal of Civil Engineering and Technology, 10(1), pp. 2796-2811.

7. Frank Stephen, S., Chockalingam, M.P., Nalanth, N. and Lekshmy Raghavan, P., 2019. Study on the fresh state properties of self compacting concrete modified with recycled concrete aggregate. International Journal of Civil Engineering and Technology, 10(1), pp 1205-1212.

8. Dayakar, P., Raman, K.V., Arunya, A. and Venkatakrishnaiah, R., 2019. Study on strength properties of sand by biocementation with eggshell. International Journal of Civil Engineering and Technology, 10(1), pp. 2770-2785.

9. Shendge, R.B., Chockalingam, M.P., Saritha, B. and Ambica, A., 2018. Swat modelling for sediment yield: A case study of Ujjani reservoir in Maharashtra, India. International Journal of Civil Engineering and Technology, 9(1), pp. 245-252.

10. Meikandaan, T.P. and Hemapriya, M., 2017. Use of glass FRP sheets as external flexural reinforcement in RCC Beam. International Journal of Civil Engineering and Technology, 8(8), pp. 1485-1501.

11. Harini, A.T., 2017. Experimental study on utilisation of ceramic wastes in concrete. International Journal of Civil Engineering and Technology, 8(8), pp. 1346-1352.

12. Ambica, A., Sartiha, B. and Anbarasan, R., 2017. Groundwater quality assessment using water quality index and GIS, Maduravoyal, Chennai, India. International Journal of Civil Engineering and Technology, 8(8), pp. 1375-1381.

13. Aswathy, M., Saritha, B. and Chockalingam, M.P., 2019. Degradation of anionic dye using $\mathrm{Fe} / \mathrm{Tio} 2$ composite by photocatalysis. International Journal of Innovative Technology and Exploring Engineering, 8(9 Special Issue 3), pp. 788-791

\section{AUTHORS PROFILE}

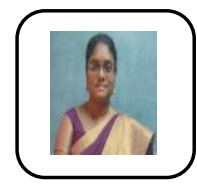

K. Anitha Assistant Professor, Department of Civil Engineering, Bharath Institute of Higher Education and Research, Chennai, India.

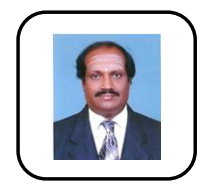

T.P. Meikandaan Associate Professor, Department of Civil Engineering, Bharath Institute of Higher Education and Research, Chennai, India.

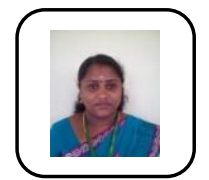

M. HemaPriya Assistant Professor, Department of Civil Engineering, Bharath Institute of Higher Education and Research, Chennai , India. 